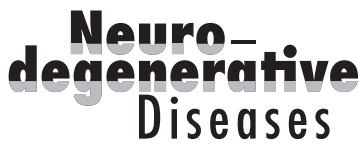

\title{
Familial Progressive Supranuclear Palsy: A Literature Review
}

\author{
Shinsuke Fujioka ${ }^{a}$ Jay A. Van Gerpen ${ }^{a}$ Ryan J. Uitti ${ }^{a}$ Dennis W. Dickson ${ }^{b}$ \\ Zbigniew K. Wszolek ${ }^{\mathrm{a}}$ \\ Departments of a Neurology and ${ }^{\mathrm{b}}$ Neuropathology, Mayo Clinic, Jacksonville, Fla., USA
}

\section{Key Words}

Familial progressive supranuclear palsy $\cdot M A P T$

\begin{abstract}
Background: Many genes/loci associated with Parkinsonian disorders have been identified. However, the genetic causes for a number of familial forms of Parkinsonian disorders remain to be elucidated. Objective: It was the aim of this paper to review the familial progressive supranuclear palsy (PSP) cases without any known gene mutations published in the English literature. Methods: We searched the PubMed database for reports of familial PSP cases without known mutations. Results: We found 19 PSP families. The mean age at onset was approximately 60 years, and the mean disease duration was about 8 years. Parkinsonism and ophthalmoplegia were most frequently reported, and a vast majority of patients manifested with these two symptoms. Other symptoms such as falls, postural instability and pyramidal signs were also common. A small subset of patients transiently responded to L-dopa therapy. Conclusion: There is an increasing number of reported familial PSP. A recently performed genome-wide association study indicated genetic factors for this condition. Furthermore, clinical, pathological and genetic investigations will open new avenues to the discovery of causative genes and new therapeutics for PSP.
\end{abstract}

(c) 2013 S. Karger AG, Basel

\section{KARGER}

E-Mail karger@karger.com

www.karger.com/ndd

\section{Introduction}

Genetic research has revolutionized the understanding of the underlying mechanisms behind Parkinson disease and Parkinsonism. To date, a number of genes for Parkinsonian disorders have been identified [1]. Progressive supranuclear palsy (PSP) is a relatively common neurodegenerative disorder and is clinically characterized by Parkinsonism (mainly bradykinesia and rigidity) and the presence of additional features such as ophthalmoplegia, pyramidal signs, postural instability, falls, and frontal disturbances [2]. Familial forms of PSP, classically thought to be a sporadic condition, have been increasingly recognized, and several families have been reported to carry MAPT mutations [3]. However, a major genetic cause has never been identified for most familial PSP cases. In this paper, we review previously described familial PSP cases.

This study is based on the invited lecture provided by Z.K. Wszolek during the 11 th International Conference on Alzheimer's and Parkinson's Disease in Florence, Italy, on March 7th, 2013. 
Table 1. Summary of clinical features (yes/no/NA) of previously reported familial PSP cases

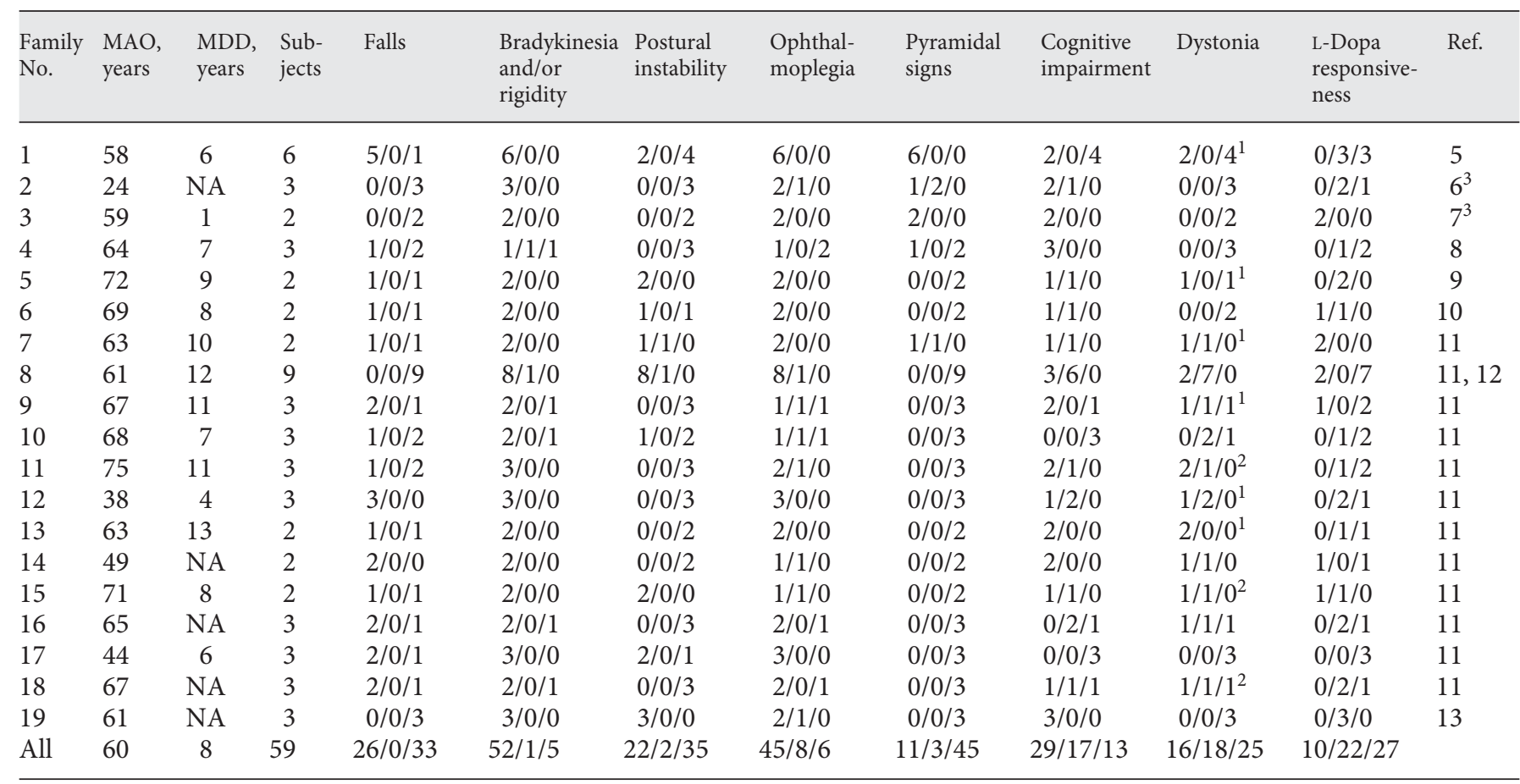

$\mathrm{NA}=$ Not available; $\mathrm{MAO}=$ mean age at onset $\mathrm{MDD}=$ mean disease duration; Ref. $=$ reference .

${ }^{1}$ Dystonia affected both the axial part of the body and the limbs. ${ }^{2}$ Dystonia prominently affected the axial part of the body. ${ }^{3}$ The authors of these papers were not able to rule out the possible diagnosis of other neurodegenerative disorders. ${ }^{4}$ Cases where clinical details were unavailable were excluded.

\section{Methods}

We searched the PubMed database from 1968 to April 2013 for all papers published in English that contained the keywords 'familial' and 'PSP' in the title or the abstract. We included cases in which at least one family member had PSP and in which clinical details were available, and we excluded cases where known gene mutations were identified.

\section{Results and Discussion}

Fifty-nine affected patients from 19 published PSP families were identified for this study (table 1). We excluded cases without detailed descriptions of clinical symptoms. The mean age at onset was approximately 60 years, and the mean disease duration was about 8 years. Parkinsonism and ophthalmoplegia were most frequently reported, and a vast majority of patients manifested with the symptoms. Falls, postural instability, pyramidal signs, cognitive impairment, and dystonia were common symptoms as well; however, information was missing in the majority of patients. A small subset of patients transiently responded to L-dopa therapy. Known gene mutations including MAPT mutations have not been identified or reported in these cases [2]. Therefore, it is possible that some of the patients could harbor MAPT mutations.

A genome-wide association study on autopsy-proven PSP identified several genetic variants, such as MAPT, STX6 and EIF2AK3 [4]. Undoubtedly, more genetic factors, including monogenic, polygenic and risk variants, as well as genetic-environmental interaction, will be discovered for this condition.

\section{Acknowledgement}

J.A. Van Gerpen, R.J. Uitti, D.W. Dickson and Z.K. Wszolek are partially supported by the National Institutes of Health/National Institute of Neurological Disorders and Stroke P50NS072187. We would like to thank Audrey J. Strongosky and Beth M. Marten for their assistance in the genealogical research and their administrative efforts, and Kelly E. Viola for her editorial assistance. 


\section{References}

1 Puschmann A: Monogenic Parkinson's disease and parkinsonism: clinical phenotypes and frequencies of known mutations. Parkinsonism Relat Disord 2013;19:407-415.

$>2$ Fujioka S, Algom AA, Murray ME, Strongosky A, Soto-Ortolaza AI, Rademakers R, Ross OA, Wszolek ZK, Dickson DW: Similarities between familial and sporadic autopsy-proven progressive supranuclear palsy. Neurology 2013;80:2076-2078.

>3 Ogaki K, Li Y, Takanashi M, Ishikawa K, Kobayashi T, Nonaka T, Hasegawa M, Kishi M, Yoshino H, Funayama M, Tsukamoto $\mathrm{T}$, Shioya K, Yokochi M, Imai H, Sasaki R, Kokubo Y, Kuzuhara S, Motoi Y, Tomiyama H, Hattori N: Analyses of the MAPT, PGRN, and C9orf72 mutations in Japanese patients with FTLD, PSP, and CBS. Parkinsonism Relat Disord 2013;19:15-20.

-4 Hoglinger GU, Melhem NM, Dickson DW, Sleiman PM, Wang LS, Klei L, Rademakers R, de Silva R, Litvan I, Riley DE, van Swieten JC, Heutink P, Wszolek ZK, Uitti RJ, Vandrovcova J, Hurtig HI, Gross RG, Maetzler W, Goldwurm S, Tolosa E, Borroni B, Pastor P, Cantwell LB, Han MR, Dillman A, van der
Brug MP, Gibbs JR, Cookson MR, Hernandez DG, Singleton AB, Farrer MJ, Yu CE, Golbe LI, Revesz T, Hardy J, Lees AJ, Devlin B, Hakonarson $\mathrm{H}$, Müller U, Schellenberg GD: Identification of common variants influencing risk of the tauopathy progressive supranuclear palsy. Nat Genet 2011;43:699-705.

5 David NJ, Mackey EA, Smith JL: Further observations in progressive supranuclear palsy. Neurology 1968;18:349-356.

6 Mata M, Dorovini-Zis K, Wilson M, Young $\mathrm{AB}$ : New form of familial Parkinson-dementia syndrome: clinical and pathologic findings. Neurology 1983;33:1439-1443.

-7 Ohara S, Kondo K, Morita H, Maruyama K, Ikeda S, Yanagisawa N: Progressive supranuclear palsy-like syndrome in two siblings of a consanguineous marriage. Neurology 1992; 42:1009-1014.

8 Brown J, Lantos P, Stratton M, Roques P, Rossor M: Familial progressive supranuclear palsy. J Neurol Neurosurg Psychiatry 1993;56: 473-476.

$\checkmark 9$ Tetrud JW, Golbe LI, Forno LS, Farmer PM: Autopsy-proven progressive supranuclear palsy in two siblings. Neurology 1996;46:931-934.
10 Gazeley S, Maguire JA: Familial progressive supranuclear palsy. Clin Neuropathol 1996; 15:215-220.

11 Rojo A, Pernaute RS, Fontan A, Ruiz PG, Honnorat J, Lynch T, Chin S, Gonzalo I, Rabano A, Martinez A, Daniel S, Pramstaller P, Morris H, Wood N, Lees A, Tabernero C, Nyggard T, Jackson AC, Hanson A, de Yebenes JG: Clinical genetics of familial progressive supranuclear palsy. Brain 1999;122: 1233-1245.

12 Ros R, Gomez Garre P, Hirano M, Tai YF, Ampuero I, Vidal L, Rojo A, Fontan A, Vazquez A, Fanjul S, Hernandez J, Cantarero S, Hoenicka J, Jones A, Ahsan RL, Pavese N, Piccini P, Brooks DJ, Perez-Tur J, Nyggard T, de Yebenes JG: Genetic linkage of autosomal dominant progressive supranuclear palsy to 1q31.1. Ann Neurol 2005;57:634-641.

13 Piccini P, de Yebenez J, Lees AJ, Ceravolo R, Turjanski N, Pramstaller P, Brooks DJ: Familial progressive supranuclear palsy: detection of subclinical cases using 18F-dopa and 18fluorodeoxyglucose positron emission tomography. Arch Neurol 2001;58:18461851 . 